\title{
Turbaner i Venedig
}

\section{Om dialektiske billeder i den moderne tyrkiske roman}

\section{Orhan Pamuk og den moderne roman}

I den tyrkiske sammenhæng er spørgsmålet om den moderne roman uløseligt knyttet sammen med nationalismen og med en forventning om, at forfatterne skal påtage sig rollen som folkeopdragere i overensstemmelse med republikkens officielle selvforståelse. Realisme, skolelærerlitteratur og patriotisk litteratur er en arv, som de nyeste forfattere forholder sig kritisk til, det gælder Orhan Pamuk, men også andre og mindre kendte som Nedim Gürsel. De er fælles om at distancere sig fra rollen som opdragere, men ikke desto mindre spiller de stadig under et postmoderne image en afgørende rolle i den tyrkiske moderniseringsproces. Og mens især Orhan Pamuk i Vesten går for at være et bud på det (post)moderne Tyrkiet, er det i en tyrkisk sammenhæng ofte meget lidt, der skiller ham fra de andre forfattere. Det er et forhold, der bidrager til en utrolig rivalisering, men også gør det særlig vigtigt at indkredse forskellene og deres betydning i en bredere modernitetssammenhæng. Når det i Tyrkiet anses for at være suspekt at være romanforfatter, hænger det sammen med det officielle Tyrkiets lange oplevelse af romanforfatterne som upålidelige forbundsfæller, som idealister, der tager det modernes emancipatoriske potentialer lidt for bogstaveligt, og som kritikere erindrer om tabuiserede sider af historien. Romanen, der egentlig skulle være republikkens kulturelle ledebillede, har ofte vist sig at rumme modstandens æstetik.

Den tyrkiske roman opstår i midten af det 19. århundrede som et led i det osmanniske imperiums moderniseringsprogram, tanzimat, der betyder nyordning. Her lægges vægt på rationalisering, koordinering, symmetri i byerne, infrastrukturen og i lovgivningen. ${ }^{1}$ Den tyrkiske roman er påvirket af

1. Josef Matuz: Das osmanische Reich. Grundlinien seiner Geschichte, Darmstadt 1985, p. $209 \mathrm{ff}$. 
fransk og russisk realisme, af Balzac og Dostojevskij. Den er i sit grundlag kulturoptimistisk, reformpræget og politisk orienteret mod vestens demokrati. Denne tendens kulminerer med etableringen af den tyrkiske republik i 1923; der opstår en stribe af heroiske forfattere, der støtter Kemal Atatürk, det gælder også de venstreorienterede forfattere, der ofte bliver sat i fængsel for deres synspunkter. ${ }^{2}$

Spørgsmålet er, om Orhan Pamuks romaner er et brud med denne tradition, som man har sagt, og om det, at han er postmoderne, udelukker, at han skulle være en del af kulturoptimismen. Det er ikke den realistiske romantradition, hans angreb er rettet imod, men brudmodernismen og avantgarden, både den franske Baudelaire-tradition og den russiske avantgardetradition omkring Majakovskij.

Pamuk følger på den måde en tendens fra 1930ernes tyrkiske litteratur, en tendens, der ikke er så synlig i prosalitteraturen, men derimod i lyrikken, og dermed siges der også noget meget centralt om hans romanform, påvirket som den er af lyrikken, både den moderne tyrkiske og den osmanniske divanlyrik. Det spørgsmål Pamuk stiller med sit forfatterskab lyder: findes der en tyrkisk roman? Om dette spørgsmål hedder det blandt andet:

"Sommetider føler jeg mig også meget ensom. Når jeg sammenligner den tyrkiske litteraturhistories problemer med den moderne litteraturs og den moderne romans historie i de vestlige lande, har jeg på fornemmelsen, at mit tøj ikke sidder rigtigt. Men det giver mig også en følelse af vitalitet... $\|^{3}$

Det svar, hans egne romaner giver, er overraskende, for han betragter romanen som et kæmpecitat, han gennemløber romanens historie, fra den realistiske roman, over den ny roman til den metarefleksive roman, som om han bagved de forskellige romanskeletter søger noget andet end det romanen kan give. I utallige interviews har han i en hegeliansk tankegang sat sine romaner ind $\mathrm{i}$ en romanhistorisk sammenhæng fra realismen i det 19. århundrede, over den tidlige modernisme til den nye franske roman og den postmoderne roman. Romanen Den sorte bog skulle så ophæve alle tendenser i sig og være den absolutte ånds roman. Set i dette perspektiv opfatter han ikke sine romaner som noget helt nyt, men som værker og former, der samler og

2. Yüksel Pazarkaya: Rosen im Frost. Einblicke in die türkische Kultur, Zürich 1982, pp. 113 126.

3. "Problemlos über meine Probleme« in Norbert Weber (Hrsg.): Schreibheft 48, Essen 1996, p. 53. 
reflekterer over det, der har været, noget i retning af romanen som det modernes museum, hvor alt er repræsenteret i samme rum side om side. ${ }^{4}$

Der har fra begyndelsen hersket en vis forvirring omkring hans romaners rødder: Borges, Auster, magisk realisme, 1001 nats eventyr, Proust, Joyce. Men disse referencer viser kun hans romaners parafraserende karakter. Det giver intet at indkredse ham på den måde, at hans romaner kan føres tilbage til en historisk oprindelse, for han drager hele den teleologiske betragtningsmåde i tvivl. Det er netop romanens historiebegreb han angriber i sin nye romanform, og det er derfor historien, der skal trækkes frem.

Pamuks historiesyn står i modsætning til såvel den tyske oplysningsmodel som til den franske, modernistiske brudteori, der går tilbage til Baudelaires begreb om det emfatisk nye. I stedet må man tale om Pamuks aktualisering af traditionen som hans modernismeteori. Det betyder, at han går ind i de ældste traditioner og genfortolker dem som dele af én eneste stor nutid. Der opstår et kæmpe nutidsrum i hans romaner, nutiden som et gigantisk mytisk rum, hvor fortidselementer er ligeså virkelige og dynamiske som det nuværende. Det er altsammen nærværende, til stede på én gang, og han betragter det altsammen som konstellationer, et begreb, der både stammer fra europæisk filosofi og fra islamisk mystik. Om Den sorte bog hedder det:

"Den sorte bog er ikke en politisk bog i almindelig forstand. Men idet den kritiserer volden i vores kultur, samfundets politisering, diskrimineringen af det fremmede, det anderledes, er det alligevel en politisk bog ... På den anden side viser Den sorte bog også den pluralistiske, demokratiske og multikulturelle side af vores samfund og er i den forstand en konstruktiv, fredelig bog. Den er ikke et opråb til revolution«. ${ }^{5}$

Med dette historiebegreb som udgangspunkt kan man se konturerne af Pamuks romanform. Den relative historieopfattelse omkring konstellation tangerer eksperimentet, men bygger især på to træk hos ham: nemlig subjektets og formens opløsning, det cartesianske subjekts opløsning og den harmoniske forms opløsning. Disse to træk holder sammen på alle hans romaner i form af identitetsproblematikken, som samtidig er et formproblem.

Man kunne tro, at Pamuk dermed afskrev formen og subjektet til fordel for en ren relativisme eller ligefrem livsfilosofi, men han fremhæver altid en

4. "Das Gewebe Istanbuls - Cebal Özian in Gespräch mit Orhan Pamuk«, in Schreibheft 48 op.cit., pp. 61-65.

5. Loc.cit., p. 64. 
momentan sammenhæng, et spor, en øjebliksepifani, en erfaring og ikke kun en kæde af oplevelser. Det mest slående udtryk for denne tendens til hele tiden at gå fra oplevelser til forsøg på samlet erfaring er sporet og detektivromanen, der i virkeligheden er alle hans romaners urform.

Hvis Siegfried Kracauer ${ }^{6}$ i tyverne læste detektivromanen som romanen om en helhed, der bestod af de atomiserede elementer i en verden, der var faldet fra hinanden, så opretholder Pamuk denne opfattelse af helheden som et muligvis illusorisk projekt. Det, der opklares i hans romaner, er næsten aldrig det afgørende, det er måske den forkerte morder, der henrettes, således i Den sorte bog, og ligeledes i Mit navn er Rød, Orhan Pamuks seneste roman. Men som et led i denne særlige, metafysiske brug af detektivromanen inddrager Orhan Pamuk næsten altid den særlige tyrkiske tradition. Han skriver sig ind i to sammenhænge, dels sufimystikken og divanlyrikken, dels den anden, traditionssøgende modernisme i Europa, især hos Proust, Musil og Thomas Mann.

Sufimystikkens udgangspunkt er jegets opgivelse af sig selv for at blive en anden og derigennem sig selv igen. Det er i Den sorte bog hele udviklingen fra første til anden del, fra Galip til Celal, det er også de to store versfortællinger, som danner grundmønster for Den sorte bog, nemlig Seyh Galips Hüsn ve Ask og Mehlevi af Rumi, som ligger bag.

Det, der sker i sufimystikken, er på én gang et tab af identitet, men samtidig en løftelse mod en erkendelse, der ligger uden for tid og rum, og som aldrig bliver beskrevet, aldrig kan beskrives. Romanens centrum er ganske vist en erfaring, men denne erfaring viser sig kun indirekte, som spor, som gåder og som spejlinger af virkeligheder: Selve virkeligheden kan ikke skildres direkte. Derfor er det vigtigt, at vi i et bestemt kapitel fra Den sorte bog - Billedernes hemmelighed - hører om det knuste spejl. Et spejl på en bar spejler et maleri af Istanbul, og netop dette spejl knuses, og det kan både betyde, at spejlet som den indirekte sandhed knuses til fordel for den direkte sandhed, eller at enhver tilgang til sandheden nu er udelukket. Sandheden om gåden betyder død, og gennem den forvandling som ikke kan beskrives.

Orhan Pamuk bruger en helt bestemt teknik for at indkredse sufimystikkens ikke-identitet. Han arbejder med divanlyrikkens dobbeltsprog. Divanlyrikkens udgangspunkt er et kodesprog af ord som have, rose, vin, elsker. Disse ord er alle verdslige, men de er samtidig del af en »this-world/ that-world polarity«, dvs. analogier til en anden verden, en metafysisk verden. ${ }^{7}$ Idet disse ord bruges, beskriver de den materielle verden som smerte,

6. Siegfried Kracauer: Das Ornament der Masse. Essays, Frankfurt a. M. 1977, p. 159.

7. Walter G. Andrews: Poetry's Voice, Society's Song. Ottoman Lyric Poetry, Seattle and London 1985, p.69. 
afstand, fravær, men peger dermed på ophævelsen af fraværet, altså opfyldelse, heling, enhed over for splittelse og opløsning.

Divandigtningen beskriver det verdslige som det uforløste, og peger dermed på det modsatte; derved rives sløret af det verdslige, og gennem en ophævelse peges der på det usynlige metafysiske, uden at det kan indfanges undtagen gennem analogier.

Pamuk bruger denne teknik allerede fra første side af Den sorte bog, hvor havesymbolet indføres og kobles sammen med gådefuldhed og uvished:

"Nu ønskede han [Galip, HG] at strejfe gennem Rüyas tæt lukkede haver, mens hun lå begravet i søvnens ro, og vandre under piletræerne, akacierne, slyngroserne i solen. $\|^{8}$

Det er begyndelsen til romanens jæger-jaget-symbolik, som slutter med beskrivelsen af døden for Celal og Rüya hhv. som avis-lig og som dukke, dvs. netop som symboler på et fravær, og derved indirekte på et symbolsk plan, som romanen aldrig kommer til at beskrive. Alt i romanen er bygget op om denne position-ophævelse-figur lige til romanens hovedarkitektur, den konstante vekslen mellem handlingsafsnit og spejlingsafsnit, mellem Galip og Gelal.

Orhan Pamuk er ofte blevet spurgt om grunden til denne genoptagelse af sufimystikken, ikke mindst i Europa hvor mange har konstateret ligheder mellem sufimystikkens fraværsmetafysik og den jødiske kabbalismes sprogmagi, og han giver altid to svar.

Det ene svar er kulturelt, det kredser om det moderne Tyrkiets historie, og ifølge denne forklaring må den moderne tyrkiske forfatter gribe tilbage til traditionen fra den osmanniske periode af poetiske grunde, fordi ingen digter kan nøjes med Kemal Atatürks sækulariserede verden, men må bruge af den gamle poetiske verdens mytologiske sprog:

"Bogen [Den sorte bog, HG] øser af den mystiske tradition. Jeg ønskede at mobilisere denne mystikkens demokratisk-litterære tradition mod den religiøse fundamentalisme. Jeg ønskede at skrive en detektivhistorie, hvor en romanhelt leder efter sin forsvundne kone. Og denne konstellation korresponderer $\mathrm{i}$ en vis forstand med sufiens klassiske rejse på sporet af livets betydning «. ${ }^{9}$

8. Orhan Pamuk: Den sorte bog, København 1990/1996, p. 11.

9. Schreibheft 48 , loc. cit., p. 65. 
Denne »reddende« begrundelse er tillokkende, for da Den sorte bog udkom i 1990 vidste ingen i Tyrkiet noget om den religiøse og poetiske fortid, og derfor fik bogen en stor betydning, men denne uvidenhed har de sidste ti år ændret sig, fordi den religiøse fortid er blevet genskabt i tyrkernes bevidsthed til ulidelighed.

Det andet svar på spørgsmålet om brugen af sufi-mystikken i Den sorte bog er, at sufimystikken ikke er historie, men aktualitet, nutid, og derfor hele tiden skal bruges som genfortolkning af verden. Det er afgørende for Pamuk, at han genbruger og ikke skaber nyt, og derfor er sufimystikken og divantraditionen ikke det ny, men fortsættelse, genbrug, udvidelse, men under alle omstændigheder er den en del af Pamuks enorme mistænksomhed mod brudmodernismen og hele avantgardetraditionen.

Denne antiavantgardisme forklarer også hans historiesyn, som netop ikke er historieoptimistisk, men relativistisk. Avantgarde og omvæltning har ifølge ham skabt ulykker nok i den vestlige verden og i Tyrkiet. Og hans roman drager konsekvensen af dette ved at aktualisere traditionen og operere med et jeg- og et formbegreb, der er bygget op omkring konstellation.

Denne skepsis over for historieoptimismen bringer ham i nærheden af den centraleuropæiske tradition, og ikke mindst i nærheden af den Milan Kundera, som han beundrer som en, der har gjort noget imod nationalismen i Tjekkoslovakiet - ligesom Pamuk har gjort det i Tyrkiet. For denne tradition er skeptisk, sprogkrisecentreret og arbejder med opløsning af store helheder til fordel for øjebliksepifanier, som Den sorte bog er fuld af. Men de store omdrejningspunkter for Pamuk er Dostojevskij og Proust.

Fra Dostojevskij har han advarslen mod vestens fremskridtstro, og måske også den folkeopdragende tendens, som spiller så tydelig en rolle i den ældre tyrkiske litteratur, men faktisk også hos Pamuk, i hans beskrivelse af den moderne verden som illusion, som det slør, hans romaner river væk, så man har udblik til den symbolske verdens gådefuldhed. Mere konkret manifesterer denne fjernelse af sløret sig i Pamuks bastante kritik af kemalismen som roden til alt ondt i Tyrkiet, og i hans nyliberalistiske grundholdning. Ifølge Pamuk ville det være ok at kurderne og islamisterne fik frihed til at præge det tyrkiske samfund, så det blev mindre centralistisk og statsmonopoliseret.

Han er fuldstændig klar over, at der ikke er nogen vej tilbage til tiden før kemalismen, men samtidig bruger han de gamle traditioner til at relativere kemalismens enorme selvtillid og det moderne tyrkiske samfunds lukkethed omkring sin nationalistiske ideologi, der jo samtidig manifesterer sig i litteraturens lovprisning af de tyrkiske dyder og det anatoliske landskabs enestående skønhed. 
Proust spiller lige fra begyndelsen en enorm rolle hos Pamuk, og det er ikke erindringens tematik, der er grunden, men identitetstemaet, dvs. jegets relativitet, således allerede i Hr. Cevdet og hans sønner. Jegets relativitet er imidlertid altid knyttet til opløsningen af totaliteten, nemlig den kulturoptimistiske tendens i Tyrkiets historie.

Jegets opløsning hænger sammen med Pamuks skepsis over for kulturoptimismen i Hr. Cevdet og hans sønner, Det tavse hus og Den sorte bog; dermed følger Pamuk Prousts tendens til at bygge sin roman På sporet af den tabte tid op omkring kritikken af den borgerlige optimisme, i Combray, i Paris; alt dette til fordel for en besværgelse af en verden, der er barok, dvs. en skyggeverden, en allegorisk verden, der er en illusionsverden, uden at Proust præsenterer en modverden, en utopi, men højst en paradoksal verden, hvor opløsningen af den borgerlige verden indirekte peger på en gådefuld og hinsides verden i korte øjeblikke, og selv disse er beskrevet som klicheer og ikke som sandheder.

Bag alt det, der i det foregående er nævnt som vigtigt for den anden modernisme - jegopløsning, formopløsning, øjebliksepifani og aktualisering af tradition - gemmer der sig et centralt begreb hos Pamuk og hos hans forgængere - især Proust - og det er oversættelsesbegrebet, der er et konstruktionsbegreb, dvs. at oversættelse for Pamuk er et nøglebegreb, fordi det kun er gennem skabelse af de eksisterende elementer i historien og i poetikken, at han kan skrive og derigennem både skabe sig selv og verden og vise, at det hele er en konstruktion, noget relativt, men samtidig det eneste mulige, der kan skabes, nemlig en skinverden, der altid kan videreudbygges; og denne oversættelsesproces er uendelig, uafsluttelig, ligesom udgangspunktet - verden, forlægget - heller ikke er originalt, men altid ufærdigt. Hverken Prousts eller Pamuks slutninger er slutninger, men begyndelser, optakter til fortsættelser. I Den sorte bog er de to hovedpersoner døde, men jegets forvandlingsproces er ikke slut, for livet er gådefuldt, intet er så gådefuldt som livet, bortset fra litteraturen, hedder det til sidst.

Da Den sorte bog udkom, blev Pamuk anklaget for at være en kynisk forfatter, der ikke kæmpede for sit folks frihed fra det tyrkiske militærdiktatur, ligesom det havde været tilfældet for mange andre forfattere, lige fra kemalismens begyndelse til i dag. Men hans svar har altid været, at litteraturen er blevet terroriseret af politisk emancipatoriske krav, så der ikke er blevet stillet æstetiske krav til værkerne. Til gengæld har han fremhævet, at han som kendt forfatter ofte har sagt og gjort noget til fordel for de politisk undertrykte, men hans politiske engagement kan nok ligge på et meget lille sted.

Og det plager ham af én bestemt grund, at han altid anklages i Tyrkiet: for at være en tyrkisk Flaubert, for at være en oversætter, der forråder sit 
lands hemmeligheder til de udenlandske fjender. Og faktisk, hvis man ser Pamuk i tyrkisk sammenhæng, så truer han med at forsvinde i en lang søjle af forfattere og intellektuelle, der stort set deler hans synspunkter: kosmopolitisme, Istanbul som den multikulturelle by, antikemalismen, sufiinteressen, nyliberalismen, tolerancen over for nyislamisterne.

Men på ét punkt er der virkelig ingen forsoning mellem Pamuk og de andre. Han kunne ikke drømme om at tigge om medlidenhed fra vesten og fremstille sig selv som en forfulgt partisan, der heroisk kæmper mod en frygtelig overmagt og har brug for trøst, hjælp, asyl, medlidenhed. Hans Tyrkiet er et moderne, vestligt, anti-folkloristisk Tyrkiet, med moderne, socialt boligbyggeri, højhuse, teknologi, hvor det faktisk er muligt at leve næsten normalt og følge med i, hvad der sker i Tyrkiet og i udlandet. Og hvis der alligevel er en klage i Pamuks forfatterskab, så skyldes den, at Tyrkiet er isoleret fra den vestlige verden, især Istanbul, hvorimod mange andre tyrkiske forfattere netop fremhæver Tyrkiets særlige identitet og enestående kultur, som vesten har løbet over ende. Pamuk mener jo ikke, at Tyrkiet er splittet mellem øst og vest, for han opfatter moderniseringsprocessen som en del af Tyrkiets og osmannerrigets egen historie, og det er noget nyt, og dybt provokerende for mange tyrkere.

Til gengæld er det dybt provokerende for Pamuk, at han har en litterær dobbeltgænger, en forfatter, som næsten skriver de samme bøger som Pamuk, skyggebøger, og som bor i Paris og taler fransk.

\section{En tyrk i Paris}

Nedim Gürsel er født i 1951, i Gaziantep i Østtyrkiet. Siden 1971 har han boet i Paris. Han har skrevet doktorafhandling om Aragons surrealisme og den tyrkiske digter Nâzim Hikmet, og i dag er han professor ved Sorbonne i litteraturvidenskab. Hans forfatterskab er tæt forbundet med et af de tyrkiske statskup, det i 1973. Omkring det har han stiliseret den landflygtige tyrkiske forfatter, der ikke mere kan vende tilbage til Tyrkiet, men er evig hjemløs, selv i Tyrkiet.

Hans første bøger fra 1980erne var elegiske og optaget af tabet: det gamle Istanbul, demokratiet, hjemstavnen. Men fra 1995 ændrer det sig radikalt. Forfatterskabet bliver voksent. Det tåler sammenligning med Orhan Pamuks to store romaner fra 1990 'erne, Den sorte bog og Mit navn er Rød. Nedim Gürsels gennembrud sker i to store romaner, en historiefilosofisk, og en kunsthistorisk.

Den historiefilosofiske roman fra 1995 hedder Bogazkesen, det er det gamle navn for Rumeli Hisari, den ene af de fæstninger som Mehmet erobre- 
ren lod bygge, lige før han erobrede Konstantinopel i 1453. I det følgende kalder jeg romanen af Nedim Gürsel for Erobreren. Ordet 'Bogazkesen' betyder halsoverskærer og afskærer af indsejlingen til Bosporusstrædet fra Sortehavet. Og i denne titel ligger allerede romanens anklage mod tyrkisk historie helt fremme. Især de første sider er rystende læsning.

Den livsglade venetianske skibskaptajn Antonio Rizzi er i året 1453 på vej ind i Bosporusstrædet med forsyninger til det belejrede Byzans. I tankerne har han allerede mødet med de fyldige byzantinske brunetter i byens bordeller. Men i stedet opbringes hans skib af osmannerne, der netop har befæstet indsejlingen; kaptajnen selv spiddes på en pæl af Mehmet Erobrerens soldater:

»Med strømmen i ryggen gled det venetianske skib under San Marco republikkens løvesmykkede flag gennem Bosporus vande mod Marmarahavet. Da kaptajnen for at runde en landtunge ændrede kurs, tog hans skæbne en brat vending. Som vågnet op af en ond drøm, for Antonio sammen og så med forundring tårnene, der pludselig rejste sig foran ham. $«^{10}$

Denne roman har to handlinger: den skildrer erobringen af Konstantinopel som en lunefuld tyrans brutale handling, og samtidig statskuppet i 1980 i Istanbul. Og læseren må opleve og gennemleve en lang historisk sammenhæng af vold og lunefuld grusomhed som den røde tråd i Tyrkiets og Osmannerrigets historie.

Den sorte bog af Pamuk foregår også omkring statskuppet i 1980. Den er uden tvivl en reaktion på dette statskup, ligesom Nedim Gürsels bog er det. Og deres konklusion er den samme: tyrkisk historie er historien om vold. Men så holder ligheden også op. Pamuk siger: den vestlige verdens historie er en historie om vold, ikke kun den tyrkiske, og løsningen er opgøret med den teleologiske historie og med vestens fremskridtsideologi.

Nedim Gürsel kredser om Tyrkiet, der er kun Tyrkiet for ham som ondskabens imperium over for det frie Frankrig, og han minder om mange tyskere, der efter nederlaget i 1945 sagde, at hvis Tyskland ikke kunne blive verdensberømt for sine digtere og tænkere, så kunne det blive det på grund af lejrene og krigsforbryderne.

I dagens Tyrkiet får Nedim Gürsel den kolde skulder, fordi han kritiserer Tyrkiet ud fra det, han husker fra 1970erne, og fordi han taler på Tyrkiets vegne i Paris. Pamuk hader ham desuden, fordi han med Erobreren har forsøgt at måle sig med Pamuk og Den sorte bog. Hvis Erobreren blot var en

10. Nedim Gürsel: Der Eroberer, Zürich 1995/2000, p. 33. 
kunstnerisk dårlig bog, ville der ikke være grund til at foretage sammenligningen. Men sagen er mere kompliceret. Nedim Gürsels roman er nemlig i modsætning til de fleste andre af hans romaner vellykket, han har noget på hjerte, noget er lykkedes for ham rent skønlitterært, næsten det samme som Pamuk, desuden har de fælles litterære forbilleder i tyrkisk litteratur. Forskellen mellem ham og Pamuk minder om den, Baudelaire skildrer i digtet Svanen fra Les fleurs du mal, mellem Baudelaires rastløse vandrer gennem Paris og Victor Hugo, der i landflygtighed på sin ø i Kanalen stadig drømmer om det Frankrig før 1852, der ikke findes mere, jamais, jamais.

Nedim Gürsels forfatter vandrer ikke rastløst rundt i Istanbul som Galip, han er ikke en steppeulv, han bor i en gammel, smuk villa ud til Bosporus, og lever elegisk, tilbagetrukket, og lider en stille, diskret Weltschmerz, mens statskuppet finder sted inde i centrum. Hvis han endelig er i centrum, så på et gammelt, fint statsbibliotek, hvor han læser osmanniske pergamentruller fra det 15. århundrede og konciperer handlingen: Om Mehmet Erobreren, der på den ene side er en tyran, en pæderast, og på den anden side en sufimystiker, der bruger religionen til at flygte fra livets og sin egen grusomhed gennem meditation.

Erobringen af Konstantinopel i 1453 paralllelliseres med det tyrkiske militærs omringning af Istanbul i 1980, hvor hus efter hus, bydel efter bydel blev finkæmmet af soldater, der arresterede, torterede og henrettede tusindvis af tyrkiske venstreorienterede, fagforeningsledere og tilfældige mennesker. Og mange flygtede til vesten, hvor de stadig bor, ofte uden at vide, hvor meget der har ændret sig i Tyrkiet, herunder Nedim Gürsel, men ikke Orhan Pamuk, som netop bor i Istanbul og prøver at leve et næsten normalt liv, men som savner, at Istanbul ikke er fuldt integreret i resten af verden, men stadig ligger i Europas periferi, undtagen i hans romaner, hvor globaliseringen for længst har fundet sted, og hvor Istanbul i virkeligheden fungerer som oversættelsens metropol for alle verdens strømninger og tendenser.

\section{Fra verdensbilleder til billedverdener}

Hvis Den sorte bog og Erobreren begge er historiefilosofiske bøger, der på hver sin måde prøver at diskutere den osmanniske fortid og dens betydning for den moderne tyrkiske republiks identitet som et demokrati, så er det tydeligt, at de begge står både i optimismens og skuffelsens tegn. Optimismen er deres fælles rod i den tyrkiske romantradition fra det 19. århundrede og dens tanzimat-tro, dens tro på den europæiske modernisering som en model for Tyrkiets fremtid. Deres pessimisme derimod skyldes, at de især 
ser negative resultater af denne modernisme i deres nutid, de står ved vejs ende omkring år 1990 og drager den konklusion, at udviklingen slog fejl, og at man ikke mere kan fremstille nutiden ved hjælp af den kulturoptimistiske roman, som den findes hos Yasar Kemal, Orhan Kemal, Nâzim Hikmet og andre.

Det kan se ud, som om Nedim Gürsel i denne forbindelse plagierer Orhan Pamuk, men det hænger nok snarere sådan sammen, at de begge søger tilbage til samme sted i den tyrkiske historie for at finde grunden til det moderne Tyrkiets konflikter og den tyrkiske romans krise. Hvis de patriotiske og optimistiske modernister fra Kemal Atatürks tidsalder i mellemkrigstiden resolut afbryder forbindelsen til det osmanniske rige og i stedet koncentrerer sig om enten nutidens Anatolien eller den førosmanniske tidsalder, dvs. den tyrkiske middelalder som emner for at skildre det moderne og dets forudsætninger, så tager Pamuk og Gürsel osmannerrigets betydning op, som det område, der er blevet forsømt og fortrængt.

I Den sorte bog og Erobreren er osmannerriget en vigtig forklaringsmodel for den politiske vold i det moderne Tyrkiet, årstallet 1453 er det tyrkiske skæbneår; for Pamuk et det et eksempel på Europas vold, for Gürsel på den tyrkiske urvold. Men på ét punkt er de enige: indtil i dag har det moderne Tyrkiet kun arbejdet på overfladen af sin historie, når det ville løsrive sig fra Osmannerriget og blive moderne. Man må gå tilbage til ondets rod, og det er her, i Osmannerrigets storhedstid, at de to forfattere mødes, og må mødes, hvis deres kritik af nutiden skal have en mulighed for at pege fremad.

Men hvis dette møde først finder sted i den historiefilosofiske romans form, så tyder deres efterfølgende parallelromaner på at de begge føler, at deres historieorienterede romanform selv er en del af problemet. Den minder stadig for meget om tanzimat-romanens ideologiske udtryk, og det de leder efter, er netop at komme om bag denne ideologi for at kunne diskutere dens holdbarhed og sandhed.

Den romanform, de begge nærmer sig i de to næste indkredsninger af den historiske problematik, er den tidlige modernismes illusionsroman fra Flaubert, Huysmann, Proust og Thomas Mann, og dens problematisering af den realistiske roman. Pamuks roman hedder Mit navn er Rød, Nedim Gürsels Billedverdener. ${ }^{11}$ Det bemærkelsesværdige ved disse to romaner er deres status som billed-romaner, Pamuk skildrer persiske miniaturer, Gürsel venetiansk renæssancemaleri, og det er tydeligt, at de med reference til illusionsromanen især interesserer sig for den franske tableau-tradition fra Diderot over Baudelaire til Proust.

11. Bogens tyrkiske titel er Resimli Dünya, da Billedverden. På tysk hedder den Turbane in Venedig. Dansk oversættelse Mit navn er Rød, Kbh. 2002. 
Det særlige ved tableau-traditionen er dens brug af billeder som måder at beskrive det uoverskuelige, paradoksale, farlige på. Målet er ikke flugt fra virkeligheden, men oversættelse af dens sammensathed til anskuelighed. I Pamuks og Gürsels tilfælde er det tydeligt, at billedernes fascination både forklarer, hvorfor løsrivelsen fra osmannerriget er så svær, og hvordan denne fascination kan gøres brugbar for nutiden, hvordan den er utopisk. Malerierne er på én gang en del af osmannerrigets selvforherligelse og iscenesættelse og stedet for kritik af dette riges magtpolitik. Det minder meget om det, Pamuk i forbindelse med Den sorte bog siger om sufimystikkens »antifundamentalistiske side«.

Pamuks roman Mit navn er Rød foregår i 1590'ernes Istanbul, og den handler om et mord på en maler, der var ved at krænke det islamiske billedforbud i billeder af sultanen. Gürsels roman handler om renæssancemaleren Gentile Bellinis berømte maleri af Mehmet Erobreren fra 1478, og samtidig om en tyrkisk kunsthistorikers rejse og ophold i nutidens Venedig. Således er deres fælles spørgsmål om en tyrkisk-osmannisk modernisme eller oplysning ikke, om den fandtes, men om den blev afbrudt helt, eller om den stadig kan reddes i dag. De to forfattere tager deres udgangspunkt i kunstens fremstilling af denne problematik.

$\mathrm{Og}$ denne problematik er forførelse, billedernes fascination i deres samtid og i de to forfatteres nutid. I Pamuks roman er forførelsen den vestlige indflydelse på osmannerrigets ortodokse tro, som er den ideologiske baggrund for mordet. I Gürsels roman er forførelsen de venetianske renæssancemaleriers evne til at ryste rationaliteten hos Mehmet Erobreren (i maleriet af ham), og hos den moderne, tyrkiske kunsthistoriker, der er på sporet af malerierne i Venedig. Da den moderne tyrkiske kunsthistorikers rationalitet dybest set rummer den samme magtfaktor som hos Mehmet Erobreren, kommer malerierne til at fungere som afsløringer af denne magt, i renæssancen og i dag. Der er tale om en forførelse væk fra magt og ideologi til en refleksion over dem og historien. I den afgørende skildring af portrættet hedder det i Gürsels roman:

"Med uventet dristighed var Gentile trængt ind i sin models indre verden og havde fremstillet Mehmet i magtens ensomhed. Med hovedet kronet af den hvide turban, der som en svulst var viklet lagvis om den røde hovedbeklædning, virkede han, som om han frøs i den røde kaftan med pelskrave. Hans ansigt var blegt og hans øjne indfaldne... Hans blik var mat. Da maleren anede Mehmets største drøm, hans hemmeligste mål ... og da han vidste, at Mehmet smedede planer, om efter Østrom også at erobre Vestrom, spærrede han Istanbuls erobrer inde mellem romerske søjler. $\aleph^{12}$ 
Selvom forførelsen i de to romaner bærer præg af den dekadenceproblematik, der findes hos Flaubert, Proust og Mann, så er den langt mindre kunstmetafysisk end hos dem og langt mere magtpolitisk relateret. Det er en forførelse væk fra endimensionalitet til paradoksalitet. Malerierne fjerner entydigheden og skaber gåder i stedet for at besvare spørgsmål. I Mit navn er Rød lader Pamuk sin chef-miniaturist sige følgende om sin tids sammensmeltning af det europæiske maleri og de persiske miniaturer:

"»Der er ingenting, der er rent, « sagde Eniste Effendi. »Når der laves et mesterstykke i kunstbøgernes rige, når et pragtfuldt maleri giver mig tårer i øjnene og gør, at det løber mig koldt ned ad ryggen, kan jeg være sikker på følgende: to ting, der hidtil aldrig har været sat sammen, er kommet sammen for at skabe noget nyt og vidunderligt ... Når mennesket i dag ikke kan prise Akbar Khans bogværksted i Hindustan nok, er det fordi, han har tilskyndet sine miniaturemalere til at indføre de frankiske mestres stil. Øst og vest tilhører Gud. Må han beskytte os mod det rene og ublandedes vilje. $\ll^{13}$

Billederne signalerer en mulighed for at leve med mange muligheder, at være fleksibel, selvkritisk, selvironisk, dvs. Moderne, og fordi der hos begge forfattere er tale om malerier fra renæssancen og Osmannerrigets storhedstid, er der således også tale om, at der ikke kun i nutiden, men allerede dengang fandtes en begyndende rationalitet og modernitet i kunsten og hos menneskene, men at denne modernitet blev afbrudt, bekæmpet og standset af andre, fundamentalistiske udviklinger.

Men der er mere endnu. For hvis begge forfattere sammenknytter historie og nutid i deres billedanalyser, så siger de ikke kun, at modernismen blev afbrudt for fire hundrede år siden, men at samme proces også er aktuel i dag, i Tyrkiet og i Europa og i resten af verden. På den måde er netop optagetheden af kunstmaleriet et tegn på en optagethed af politik, men med andre midler end de realistiske forgængere.

Handlingen i de to romaner er utrolig forskellig. Pamuks roman har kun Istanbul som centrum, alt ses derfra. Gürsel ser samtidig Istanbul fra Venedig/vesten, i hans roman er der en stadig dobbeltbevægelse mellem den moderne tyrk i vesten og renæssancemaleren i Istanbul. Men den afgørende forskel ligger et andet sted. Hos Gürsel er den moderne kunsthistoriker en mandschauvinist, der prøver at erobre hunkønnet på samme brutale måde

12. Nedim Gürsel: Turbane in Venedig, Zürich 1999/2002, p. 261.

13. Orhan Pamuk: Mit navn er Rød, Kbh. 2002, p. 208. 
som Mehmet Erobreren indtog Konstantinopel, med de helt store kanoner. Med Thomas Manns Døden $i$ Venedig som baggrundsplot er hans rejse en dødsrejse, han dør under et voldtægtsforsøg, samtidig med at de malerier, han har analyseret, sprænger magtens snævre rammer og peger på et alternativ til magten. I de sidste linjer af Billedverden dør kunsthistorikeren, hvis navn Kâmil Uzman betyder den fuldkomne ekspert, efter et knivstik fra en venetiansk prostitueret, og han oplever først da billedernes utopiske sandhedsværdi:

"Derfor var verden så farverig og smuk. Som billedverdenen. Men efterhånden fjernede den modsatte bred sig. Kâmil Uzman, professor i kunsthistorie, ville rejse sig med de sidste kræfter; med hånden på det blødende sår prøvede han forgæves - nøgen som han var - at støtte sig til stolen. Og så faldt han pludselig til jorden. Han var død. « ${ }^{14}$

Hos Nedim Gürsel kommer læseren ud af fortryllelsen. Læseren (og kunsteksperten) må til syvende og sidst sande, at billedernes fortryllelse ikke kun er en legitimation af magten, men også dens ophævelse. I Nedim Gürsels gestus genfinder man den tyrkiske forfatter som folkepædagog. Pamuks roman bliver i forførelsen, vi kommer ganske vist i glimt ud af magtsfæren og oplever alternativer og befrielser, i form af mordets opklaring, i form af kærlighed. Men det er undtagelser, i det meste af romanen gennemtrænges livet af et stort, hvidt lys, det er sultanens lys, der fastholder alle i sin magt ved at fascinere dem. Det at forførelsen hos Pamuk både er kritikken af fundamentalismen og en del af den, viser den store forskel mellem ham og Gürsel, forskellen på Gürsels politiske korrekthed og Pamuks poetiske korrekthed. Tilsammen giver de to romaner et klart billede af splittelsen mellem det modernes status i Tyrkiet og den sufi- og divan-tradition, som både er kilden til det moderne og den største trussel imod det, hvis dens forførelse ikke reddes for nutiden.

14. Op.cit. p. 401 . 